\title{
Epidemiological profile of the
}

\section{homeless population assisted by}

voluntary initiative and the social

impact on access to healthcare: an

\section{investigative study in Curitiba, Brazil}

\author{
Rafael Senff Gomes ${ }^{1}$, Luiza Cardoso de Lima Passoni², \\ Ricardo Sirigatti ${ }^{3}$ and Francelise Bridi Cavassin ${ }^{4 *}$ \\ ${ }^{1}$ Faculdades Pequeno Príncipe (FPP); Curitiba, Brazil \\ 2Universidade Estadual do Oeste do Paraná (UNIOESTE); Cascavel, Brazil \\ ${ }^{3}$ World Doctors Organization; Curitiba, Brazil \\ ${ }^{4}$ Medical Sciences Department, Faculdades Pequeno Príncipe (FPP); Curitiba, Brazil
}

\section{Summary}

Objective: The study aimed to describe the epidemiological profile of the homeless population and report the social impact on healthcare services provided by a voluntary initiative during one-year of follow-up.

Method: This is an investigational study, carried out in an important capital-city of southern Brazil, which included 509 individuals in 2019. Findings were divided into three segments: sociodemographic, substance use/abuse and impact on healthcare.

Results: The sociodemographic profile found was predominantly male, white, single, heterosexual, educated in elementary or high school, in regular use of legal and/or illegal substances, and living as homeless for less than a year. The impact of assistance provided on the perception of individuals who returned in subsequent actions was evident.

Conclusion: The significant increase in the number of homeless people in large urban centers can benefit from the support of non-profit organizations to address the deficiencies faced in accessing basic health services. Based on this, we seek to advance in the development of new policies that improve local healthcare for the vulnerable population, to be more assertive to their needs.

\section{Introduction}

The $20^{\text {th }}$ century in Brazil was characterized by rural exodus and abrupt urbanization, which caused the exclusion of part of these rural migrant populations. These individuals faced many adversities in their engagement in work, education, and healthcare, worsened by social and geographical inequalities in urban areas resulting from economic development dissociated from social progress. These conflicts were intensified by the absence of public strategies, condemning a portion of this population to homelessness, and this value is increasing every year [1,2].

According to the first National Census and Research of
More Information

*Address for Correspondence: Francelise Bridi Cavassin. Faculty of Medical Sciences, Faculdades Pequeno Príncipe (FPP). 333 Iguaçu Avenue, Curitiba-PR, Brazil. Tel: +55 41996961251 ;

Email: francelise.cavassin@professor.fpp.edu.br

Submitted: June 26, 2021

Approved: July 06, 2021

Published: July 07, 2021

How to cite this article: Gomes RS, Passoni LCL, Sirigatti R, Cavassin FB. Epidemiological profile of the homeless population assisted by voluntary initiative and the social impact on access to healthcare: an investigative study in Curitiba, Brazil. J Community Med Health Solut. 2021; 2: 015-020.

DOI: 10.29328/journal.jcmhs. 1001010

Copyright: @ 2021 Gomes RS, et al. This is an open access article distributed under the Creative Commons Attribution License, which permits unrestricted use, distribution, and reproduction in any medium, provided the original work is properly cited.

Check for updates

OPEN ACCESS 
as other overnight accommodations as a place of temporary residence. Nine years later, the Brazilian government approved the law $n \div$. 13,714, which instituted and justified its assessment for health services [6]. However, in practice, the access of the homeless population to this service occurs mainly in urgent and emergency situations, disfavoring the longitudinal follow-up plan for individual healthcare [7].

Among the obstacles to the evaluation of the public health service by this population, it can been cited the lack of time, difficulties in monitoring their treatment because of the scarcity of resources, absence of personal documents, in addition to the discrimination present within the health service [7]. Finally, due to the itinerary of this population, the Brazilian Institute of Geography and Statistics (IBGE) does not consider it statistically [8]. In an attempt to fill this deficit in accessing the public health system, non-governmental and nonprofit voluntary organizations (NGOs) become significant players in the local scenario [9].

Curitiba, capital located in the south of Brazil, remains the most populous city in the State of Paraná and the eighth most populous in the country, with 1,933,105 inhabitants. The Social Action Foundation (FAS), a government agency that provides social assistance to the homeless population, presents in its last registration, until September 2019, more than 2,400 people in this situation [10]. Parallel to the increase of the homeless population in the capital, a branch of a non-governmental organization, first originated in the city of São Paulo and inspired by an American NGO, was installed in Curitiba. Subsequently, other regions also implemented the services in their localities.

The activities in Curitiba took place in early June 2018. Currently, monthly actions are held in a central square in the city, and provide general health services in the medical, dental, nursing, nutritional, psychological, pharmaceutical, biomedical, and physiotherapeutic areas. The purpose of the study was to describe the epidemiological profile of the homeless population and report the social impact on healthcare services provided by voluntary initiative during a year of follow-up.

\section{Methods}

This is an investigative study, with a quantitative approach. Our sample consists of the medical records of individuals attending medical consultations in ten actions all over 2019, more precisely on: January 20, March 16, April 14, May 19, June 16, 28 July, August 24, September 29, and October 8. There were no actions in the months of February and November due to unfavorable weather conditions.

Although the activities started in June 2018, we decided to include the full year of 2019 because that was when the medical records were standardized, which allowed us to have a uniform data analysis. In addition, a full year of follow-up provided a better observation of the medical care provided and attendance to actions by homeless individuals. The medical records are commonly filled out by health professionals but also by medical students who regularly participate in monthly actions, registered, and trained by the organization.

Medical records of individuals aged 18 years or older who had their first medical care at the NGO in 2019 were included. Minors, even if they were with a legal guardian during the consultation, individuals who received some other nonmedical care, incomplete medical records and individuals who had been followed up since the previous year were excluded from the study.

For the identification of the epidemiological profile, data were divided into three segments: sociodemographic, substance use/abuse and the organization's impact on healthcare for the homeless population. The sociodemographic category comprised gender, sexual orientation, age, ethnicity, marital status, time and reason for homelessness, place of overnight stay, source of income and use of services provided by the local government. The second segment comprised the use or abuse of legal and/or illegal substances, which were consumed and periods of abstinence. Data on the provision of medicines for individuals assisted by the NGO, prescription or use of contraceptives, recurrence, and attendance of individuals in monthly actions and medical evolution were addressed in the third category. Descriptive methods using the Excel ${ }^{\circledR}$ program were used for compilation and analysis.

This research was submitted and approved by the ethics and research committee on June 17th, 2020, under approval No. 4,093,022.

\section{Results}

During a full year of activities 1,660 medical consultations were held. Following the inclusion criteria previously presented, 509 medical records were eligible for this research.

The sociodemographic profile (Table 1) shows a predominance of male individuals $(85.07 \%)$, between 36 and 45 years old (31.63\%), white (52.85\%), single marital status (65.03\%), heterosexual (85.85\%) and elementary school (44.60\%), having concluded or not. The profile also shows that more than half of those included reported living on the street for less than a year (54.42\%), and the main reason cited would be for family conflicts (41.85\%). In the subgroup "other" reasons for being on the streets, there were predominantly judicial problems, diseases, free will and migration. Other relevant information points to the street as the main dormitory (51.08\%) and mendicancy as the main source of money (24.75\%). The subgroup "other" dormitories also included the Reference Centers for Street Population (POP), social hotels and friends' houses. As for "other" sources of income, casual work, government benefits and street commerce were mentioned. For more than $80 \%$ of 
Table 1: Sociodemographic profile of the homeless population, Curitiba, Brazil.

\begin{tabular}{|c|c|}
\hline Variable & $n(\%) n$ total $=509(100 \%)$ \\
\hline \multicolumn{2}{|l|}{ Gender } \\
\hline Male & $433(85.07 \%)$ \\
\hline Female & $70(13.75 \%)$ \\
\hline Others & $6(1.18 \%)$ \\
\hline \multicolumn{2}{|l|}{ Age (years) } \\
\hline $18-25$ & $59(11.59 \%)$ \\
\hline $26-35$ & $133(26.13 \%)$ \\
\hline $36-45$ & $161(31.63 \%)$ \\
\hline $46-60$ & $131(25.74 \%)$ \\
\hline$>60$ & $24(4.72 \%)$ \\
\hline Did not know & $1(0.20 \%)$ \\
\hline \multicolumn{2}{|l|}{ Ethnicity } \\
\hline White & $269(52.85 \%)$ \\
\hline Brown (mixed race) & $164(32.22 \%)$ \\
\hline Black & $52(10.22 \%)$ \\
\hline Indigene & $8(1.57 \%)$ \\
\hline Yellow & $5(0.98 \%)$ \\
\hline Missing information & $11(2.16 \%)$ \\
\hline \multicolumn{2}{|l|}{ Scholarity } \\
\hline Unlettered & $22(4.32 \%)$ \\
\hline Elementary school & $227(44.60 \%)$ \\
\hline High school & $187(36.74 \%)$ \\
\hline University & $34(6.68 \%)$ \\
\hline Technical education & $14(2.75 \%)$ \\
\hline Literate & $17(3.34 \%)$ \\
\hline Missing information & $8(1.57 \%)$ \\
\hline \multicolumn{2}{|l|}{ Sexual orientation } \\
\hline Heterossexual & $437(85.85 \%)$ \\
\hline Homossexual & $17(3.34 \%)$ \\
\hline Bissexual & $11(2.16 \%)$ \\
\hline Missing information & $44(8.64 \%)$ \\
\hline \multicolumn{2}{|l|}{ Marital status } \\
\hline Single & $331(65.03 \%)$ \\
\hline Divorced & $73(14.34 \%)$ \\
\hline Married & $65(12.77 \%)$ \\
\hline Widower / Widow & $17(3.34 \%)$ \\
\hline Missing information & $23(4.52 \%)$ \\
\hline \multicolumn{2}{|l|}{ Time of homelessness (in years) } \\
\hline$<1$ & $277(54.42 \%)$ \\
\hline $1-2$ & $77(15.13 \%)$ \\
\hline $3-5$ & $34(6.68 \%)$ \\
\hline$>5$ & $110(21.61 \%)$ \\
\hline Missing information & $11(2.16 \%)$ \\
\hline \multicolumn{2}{|l|}{ Reason of homelessness } \\
\hline Familiar conflict & $213(41.85 \%)$ \\
\hline Unemployment & $203(39.88 \%)$ \\
\hline Substance use/abuse & $149(29.27 \%)$ \\
\hline Others & $70(13.75 \%)$ \\
\hline \multicolumn{2}{|l|}{ Sleeping place } \\
\hline Street & $260(51.08 \%)$ \\
\hline Hostel & $199(39.10 \%)$ \\
\hline Sleep-inn & $42(8.25 \%)$ \\
\hline Others & $73(14.34 \%)$ \\
\hline \multicolumn{2}{|l|}{ Source of income } \\
\hline Mendicancy & $126(24.75 \%)$ \\
\hline Recycling & $98(19.25 \%)$ \\
\hline Car keeper & $91(17.88 \%)$ \\
\hline Others & $349(68.56 \%)$ \\
\hline \multicolumn{2}{|l|}{$\begin{array}{l}\text { Usage of Governmental Supporting Services } \\
\text { (more than one could be chosen) }\end{array}$} \\
\hline Hostel & $266(52.26 \%)$ \\
\hline Reference Centers for Street Population & $266(52.26 \%)$ \\
\hline Social Action Foundation & $206(40.47 \%)$ \\
\hline Psychosocial Care Center & $125(24.56 \%)$ \\
\hline Hospitalization & $125(24.56 \%)$ \\
\hline Social Assistance Reference Centers & $102(20.04 \%)$ \\
\hline Social Assistance Specialized Reference Center & $88(17.29 \%)$ \\
\hline
\end{tabular}

individuals, they benefit from government support services. Hostels and POPs were the main and equally cited $(52.26 \%$ each).

For the evaluation of substance use/abuse, it was found that 400 out of the 509 individuals report to be addicted. A small fraction considers themselves to be non-addicts ( $n=107$ ). Table 2 shows the patterns of substance use/abuse, with nicotine (71\%), alcohol (66.25\%), marijuana (38.5\%) and crack $(31.5 \%)$ being the main ones. Some individuals have a history of abstinence $(65.17 \%)$ and others who have never stopped their addiction (28.11\%).

The third segment evaluated was the attendance of individuals in the NGO's actions during 2019 (Table 3). A high number of 369 , which means more than $72 \%$, did not return after the first clinical visit. In addition, of those who returned in

Table 2: Pattern of substance use/abuse by homeless individuals in Curitiba, Brazil.

\begin{tabular}{|c|c|}
\hline Variable & $\begin{array}{c}\boldsymbol{n}(\mathbf{\%}) \\
n \text { total }=\mathbf{5 0 9}(\mathbf{1 0 0} \%)\end{array}$ \\
\hline Licit and/or illicit substances use/abuse & \\
\hline Yes & $400(78.59 \%)$ \\
\hline No & $107(21.02 \%)$ \\
\hline Missing information & $2(0.39 \%)$ \\
\hline Used substance & \\
\hline Cigarette & $284(71.00 \%)$ \\
\hline Alcohol & $265(66.25 \%)$ \\
\hline Marijuana & $154(38.50 \%)$ \\
\hline Crack & $126(31.50 \%)$ \\
\hline Cocaine & $92(23.00 \%)$ \\
\hline Popper/shoe glue & $23(5.75 \%)$ \\
\hline Ecstasy & $19(4.75 \%)$ \\
\hline
\end{tabular}

Table 3: Impact on access and improvement of the health of the homeless population served by a voluntary initiative in Curitiba, Brazil.

\begin{tabular}{|c|c|}
\hline Variable & $\begin{array}{c}n(\%) \\
n \text { total }=509(100 \%)\end{array}$ \\
\hline \multicolumn{2}{|c|}{ Returned after the first attendance } \\
\hline Yes & $140(27.50 \%)$ \\
\hline No & $369(72.50 \%)$ \\
\hline \multicolumn{2}{|c|}{ How many times has returned } \\
\hline Once & $94(67.14 \%)$ \\
\hline Twice or more & $46(32.86 \%)$ \\
\hline \multicolumn{2}{|c|}{ Health evolution of those who returned } \\
\hline Yes & $101(72.14 \%)$ \\
\hline No & $27(19.29 \%)$ \\
\hline Indifferent & $12(8.57 \%)$ \\
\hline \multicolumn{2}{|l|}{ Medication prescription } \\
\hline Yes & $289(56.78 \%)$ \\
\hline No & $84(16.50 \%)$ \\
\hline Missing information & $136(26.72 \%)$ \\
\hline \multicolumn{2}{|c|}{$\begin{array}{l}\text { Continuous use medications take-out on monthly } \\
\text { actions }\end{array}$} \\
\hline Yes & $32(20.00 \%)$ \\
\hline No & $125(78.13 \%)$ \\
\hline Missing data & $3(1.88 \%)$ \\
\hline \multicolumn{2}{|c|}{ Prescription and application of contraceptives } \\
\hline Yes & $6(11.11 \%)$ \\
\hline No & $33(61.11 \%)$ \\
\hline Missing information & $15(27.78 \%)$ \\
\hline
\end{tabular}


subsequent actions, $67 \%(n=94)$ did it only once and $32.86 \%$ twice or more. Regarding the use of medicines for continuous use and the provision of these medicines by the NGO, 160 individuals reported using some medicine daily, with $20 \%$ of these individuals considering having benefited from medical monitoring and medication withdrawal in monthly actions. Still, in only six of the 54 records of childbearing age women attended by the organization contain information on the use and withdrawal of oral contraceptives or intramuscular application provided in the actions.

Finally, the last data referring to the third segment, points to satisfaction with a significant improvement in individual health for $72 \%$ of the individuals who returned for new consultations after the first medical care.

\section{Discussion}

For the first time, the epidemiological profile of the homeless population attended by a non-governmental organization its social impact on healthcare practices, was carried out in Curitiba, Brazil.

In agreement with previous published Brazilian data [1116], the studied population is composed predominantly of single and heterosexual men, with an average age of 30 to 40 years old. However, a first divergence observed in our study was ethnicity, which attributed a predominance of whites, in disparityofmoststudiesfoundintheliterature [11,13,14,16-19]. This discrepancy is probably due to the ethnic diversity of the locations considered and the few samples of this population in some studies, such as a study about the Brazilian Midwest region [19], with 43 individuals, and another about the South region [18], with only ten. Another important observation is that some of the classifications differentiated only whites or non-whites $[13,19]$, which ends up considering more than one ethnicity in the last category, consequently implying a higher percentage. However, there was an article about the Northeast region of Brazil [15] that presented a percentage of $40 \%$ white, $30.5 \%$ black and $29.5 \%$ brown, a pattern similar to our results.

The homeless population of Curitiba has a limited elementary school education profile, regardless of its conclusion, a similar fact found by Halpern, et al. [17] and by Hungaro, et al. [11] who carried out their studies in Brazilian capitals in the Southeast, Midwest, Northeast and South regions in the years 2011 to 2012 and 2015 to 2018 , respectively. Two other studies $[20,21]$, showed a prevalence of incomplete elementary education, and a third ${ }^{15}$ mentions only 'elementary education profile'. We found other research conducted in capital cities that addressed public shelters, with 342 [14] and 353 [16] individuals and also therapeutic communities involving 342 [14] and $481[22,23]$ participants, who demonstrated an average stay of 5 to 9 years in elementary school, for half of them. These data expose the difficulties faced by this group in accessing education.
Still on schooling, 187 individuals (or almost $37 \%$ ) reported having completed high school. This data was relatively similar to the study of Halpern, et al. [17] that categorized high school and higher education together, without informing the exact value of each. Silva, et al. [15], in 2019, with a lower number of total participants (105) showed a high school completion percentage of $18.1 \%$.

The main reasons given for living on the streets were family conflict, unemployment and substance use/abuse, in line with other authors [10,19] and a review [24] that brought together studies between 2006 and 2016. Legal problems and migration were also pointed out as generators of homeless by our study, but no data were found for comparison in the literature.

Something curious about the average duration in years of living on the streets was that in our study we found a predominance of less than a year (of individuals living in this condition), while studies from the central-west region reported an average time of 90 days [22,23,25], from the southern region, less than five years [11] and from the northeast, 13 years [15]. We were unable to establish an adequate reason for such variability.

The most popular places to spend the night reported were the street itself, hostels and sleep-inns, POP Centers, social hotels, and friends' houses. Faria, et al. [20] stated that in Belém, northern Brazil, individuals sleep preferentially on the streets and in abandoned buildings. Hungaro, et al. [11] brings, in addition to those already mentioned, cheap accommodations, motels and hostels.

We realized that the search for support services occurs to meet other needs, such as bathing, safety, food, and health. In some studies [21,24] it is reported that POP Centers are the base of this population, representing a safe place to reestablish the link with society and find their immediate needs. Despite seeking support services, the homeless population also carries out informal paid activities to earn money. Predominant monetary sources were charity, recycling, and car maintenance, in order of importance. These data correspond to other studies $[11,15,18,20,24]$ that report their individuals integrating the informal labor market. However, for Schervinski [18] government benefits were identified as the main monetary source for $80 \%$ of respondents, quite different from our survey, which found a lower percentage, represented by less than $16 \%$.

The use/abuse of legal and illegal substances had a prevalence of almost 79\%. This high predominance of users is described in the literature [16,17]. In some cases, higher percentiles can be found, as shown by Farias, et al. [20], who obtained an impressive rate of $92.5 \%$. Many other national studies address this theme [11,14,15,20,22,23,25,26]. We emphasize that Sicari and Zanella, [24] discussed the role of 
substance use/abuse in the lives of this population, including as a reason to be on the street, although it is a mechanism for survival against the adversities suffered in this situation. Another mention is about the young age of experimentation, which leads to addiction.

When considering all medical consultations held in 2019, there was prescription, donation, or application of medicines in $57 \%, 20 \%$ and $11 \%$ of them, respectively. According to Cunha [1], in the National Survey of the Homeless Population carried out in 2009 , about $20 \%$ of this population were in use of medicines provided by the government's basic health units or through donations from institutions or other individuals. This information supports the relevance of voluntary organizations to the health needs of the homeless population, including as a complement to other institutions providing healthcare $[7,9]$.

Finally, regarding the social impact of voluntary services provided by the organization, our study showed that close to $30 \%$ of homeless individuals who had their first care in 2019 returned a second time, and a third of them returned two or more times in subsequent actions. We consider that this low percentage mentioned results from the itineraries and migrations common to the homeless', from the personal and individual difficulties in following the proposed medical care, in addition to the conceptions about health and illness, beliefs and the notion of self-care intrinsic to the population [27]. On the other hand, we highlight that, of those who sought more than once the medical services offered, $72 \%$ reported clinical improvement. Possibly, this positive fact is a consequence of the format of the service provided, which focuses on getting closer to the reality of the population. Also, because it happens monthly in the public space they occupy, it favors logistics, reduces prejudice and, mainly, facilitates access to basic healthcare [27].

The detailed data here presented allowed us to describe, for the first time, the epidemiological profile of the homeless population assisted by voluntary initiative as well as its social impact on healthcare practices. Our main limitation was the population sample that refers to those who sought medical care offered by the NGO during one-year of activities and may not reflect the entire homeless population of the city. Even so, we consider that this limiter did not compromise our study. Despite the difficulties of regular adherence by the population in monthly actions, those who return for follow-up report a positive improvement in their initial health status.

We hope the study findings can inspire and assist further projects focused on health promotion for the most vulnerable and encourage doctors and other health professionals to get involved with volunteering. Based on this research, we seek to progress in the development of new policies to improve healthcare for the homeless population to be more assertive to their needs.

\section{References}

1. Cunha JVQ, Rodrigues M. Pesquisa Nacional Sobre a População e Situação de Rua. 2009; http://www.mds.gov.br/webarquivos/ publicacao/assistencia_social/Livros/Rua_aprendendo_a_contar.pdf

2. Marcondes NAV, de O. Chamon EMQ, de Castro MACD. Impasse entre o Processo de Urbanização no Brasil e a População em Situação de Rua: uma Análise Crítica. Rev Ensino Educ. e Ciências Humanas. 2017; 18: 1.

3. Natalino MAC, Estimativa Da População Em Situação De Rua No Brasil. Marco Antonio Carvalho Natalino, Texto Para Discussão IPEA. 2016; 36. http://repositorio.ipea.gov.br/bitstream/11058/7289/1/td_2246.pdf

4. Natalino MAC. Estimativa da população em situação de rua no Brasil (setembro de 2012 a março de 2020), IPEA. Disoc. 2020; 73.

5. Brasil, Decreto $n^{\circ} 7.053$, de 23 de Dezembro de 2009, Brasília. 2009 http://www.planalto.gov.br/ccivil_03/_Ato2007-2010/2009/Decreto/ D7053.htm\#: :text=Para fins deste Decreto\%2C considera,áreas degradadas como espaço de A. http://www.planalto.gov.br/ccivil_03/_ ato2007-2010/2009/decreto/d7053.htm

6. Brasil, Lei N. 13.714 De 24 De Agosto De 2018, Brasília, DF. 2018 http://www.planalto.gov.br/ccivil_03/_Ato2015-2018/2018/Lei/L13714. $\mathrm{htm} \% 0$ Ahttp://pesquisa.in.gov.br/imprensa/jsp/visualiza/index.jsp?dat $a=27 / 08 / 2018$ \&jornal $=515$ \&pagina $=3 \&$ totalArquivos $=187$

7. Aguiar MM, Iriart JAB. Meanings and practices associated with health and illness among the homeless in Salvador, Bahia State, Brazil. Cad Saude Publica. 2012; 28: 115-124.

PubMed: https://pubmed.ncbi.nlm.nih.gov/22267071/

8. De Estado S, Justiça DA, Direitos TE, Gandour Thomé E. Guia De Apoio: Informações E Serviços De Atenção Para A População Em Situação De Rua Do Paraná. Curitiba-PR. 2018.

9. Yanacopulos H. NGOs (Nongovernmental Organizations), in: Int Encycl. Public Heal., Elsevier Inc. 2008: 536-542.

10. Fundação de Ação Social. Documento 74-002-462/2019. 2019.

11. Hungaro AA, Gavioli A, Christóphoro R, Marangoni SR, Altrão RF, et al. Homeless population: characterization and contextualization by census research. Rev Bras Enferm. 2020; 73: e20190236.

PubMed: https://pubmed.ncbi.nlm.nih.gov/32609214/

12. de A Patrício ACF, da Silva RAR, de Araújo RF, da Silva RF, de S GT. et al. Common mental disorders and resilience in homeless persons. Rev Bras Enferm. 2019; 72: 1526-1533.

PubMed: https://pubmed.ncbi.nlm.nih.gov/31644740/

13. Peiter P, Belmonte P, Teixeira M, Cobra G, Lacerda A. Homeless crack cocaine users: Territories and territorialities in the constitution of social support networks for health. Soc Sci Med. 2019; 227: 111-118. PubMed: https://pubmed.ncbi.nlm.nih.gov/30297160/

14. Pinheiro RS, dos S Carvalho PMR, de Matos MA, Caetano KAA, de Paula $A C$, et al. Human immunodeficiency virus infection and syphilis among homeless people in a large city of Central-Western Brazil: prevalence, risk factors, human immunodeficiency virus-1 genetic diversity, and drug resistance mutations. Braz J Infect Dis. 2021; 25: 101036. PubMed: https://pubmed.ncbi.nlm.nih.gov/33248020/

15. dos S TH. Calisto SMM, de Carvalho ACM, Magalhães HJC, Monteiro Neto $\mathrm{V}$, et al. Prevalência das hepatites $\mathrm{B}$ e $\mathrm{C}$ em moradores de rua em São Luís-MA, Rev. Investig. Biomédica. 2019; 10: 219.

16. CarvalhoPMRDS, deMatosMA, MartinsRMB, PinheiroRS, CaetanoKAA et al. Prevalence, risk factors and hepatitis $B$ immunization: helping fill the gap on hepatitis B epidemiology among homeless people, Goiânia, Central Brazil. Cad Saude Publica. 2017; 33: e00109216. PubMed: https://pubmed.ncbi.nlm.nih.gov/28792993/

17. Halpern SC, Scherer JN, Roglio V, Faller S, Sordi A, et al. Vulnerabilidades clínicas e sociais em usuários de crack de acordo com a situação de moradia: Um estudo multicêntrico em seis capitais Brasileiras. Cad Saude Publica. 2017; 33. 
18. Schervinski AC, Negrão Merry C, Evangelista IC, Cardoso Pachedo V. Atenção à saúde da população em situação de rua. Extensio Rev. Eletrônica Extensão. 2017; 14: 55.

19. Souza Antunes R, Ferreira De Souza AP, De Fátima E, Xavier $P$, Borges PR. Parasitoses intestinais: prevalência e aspectos epidemiológicos em moradores de rua Intestinal parasites: prevalence and epidemiological aspects in homeless people. RBAC. 2019; 51: 6 .

20. da S Farias DC, Rodrigues ILA, Marinho IC, Nogueira LMV. Homens vivendo em situação de rua e a atenção primária em saúde. Saúde (Santa Maria). 2017; 43: 1-8.

21. Valle FAAL, Farah BF. A saúde de quem está em situação de rua: (in)visibilidades no acesso ao Sistema Único de Saúde. Physis Rev. Saúde Coletiva. 2020; 30: 2020.

22. Barros CVDL, Galdino Júnior H, Rezza G, Guimarães RA, Ferreira $\mathrm{PM}$, et al. Bio-behavioral survey of syphilis in homeless men in central Brazil: A cross-sectional study. Cad Saude Publica. 2018; 34.
23. Brunini SM, Barros CVDL, Guimarães RA, Galdino Júnior H, Rezza G, et al. HIV infection, high-risk behaviors and substance use in homeless men sheltered in therapeutic communities in Central Brazil. Int J STD AIDS. 2018; 29: 1084-1088.

PubMed: https://pubmed.ncbi.nlm.nih.gov/29862902/

24. Sicari AA, Zanella AV. Pessoas em Situação de Rua no Brasil: Revisão Sistemática, Psicol. Ciência e Profissão. 2018; 38: 662-679.

25. Ferreira PM, Guimarães RA, Souza CM, Guimarães LCDC, Barros CVDL, et al. Exposure to hepatitis $C$ virus in homeless men in Central Brazil: A cross-sectional study. BMC Public Health. 2017; 17: 90. PubMed: https://pubmed.ncbi.nlm.nih.gov/28100196/

26. de A Patrício ACF, de Figueiredo MSBR, da Silva DF, Rodrigues BFL, da Silva RF, et al. Condições de risco à saúde: pessoas em situação de rua. Rev Enferm. UERJ. 2020; 28: e44520.

27. Silva LMA, da S Monteiro I, de Araújo ABVL. Saúde bucal e consultório na rua: o acesso como questão central da discussão. Cad Saúde Coletiva. 2018; 26: 285-291. 